\title{
THE ROLE OF EDUCATION IN PROMOTING SOCIAL INNOVATION PROCESSES IN THE SOCIETY
}

\author{
Svetlana Surikova \\ University of Latvia. Latvia \\ Karine Oganisjana \\ Riga Technical University, Latvia \\ Gunta Grinberga-Zalite \\ Latvia University of Agriculture, Latvia
}

\begin{abstract}
The purpose of the paper is to clarify the role of education in promoting social innovation processes in the society based on the main findings of the theoretical study conducted from October 2014 to January 2015 within the project "Involvement of the Society in Social Innovation for Providing Sustainable Development of Latvia" supported by the National Research Program 5.2. EKOSOC-LV. The paper provides the analysis of causal interaction between social innovation and education, as well as two conceptual models which disclose the relationship between social innovation and education and the triple role of education in promoting social innovation; both are elaborated by the authors.
\end{abstract}

Keywords: conceptual model, education, social innovation, theoretical study.

\section{Introduction}

The theoretical study conducted within the project 5.2.7. "Involvement of the Society in Social Innovation for Providing Sustainable Development of Latvia (EKOSOC-LV)" aimed to work out the methodology and basis for conducting the empirical research in order to reveal the character of social innovation processes in the Latvian society for elaborating a model of active involvement of different stakeholders in social innovation. This theoretical research was based on the scientific literature and sources from:

- $\quad$ EBSCO host, Emerald Insight, Cambridge Journals, JSTOR, ProQuest Dissertations \& Theses Global, OECD iLibrary, SAGE Journals, Science Direct databases;

- ec.europa.eu, www.tepsie.eu, www.innovation.cc, youngfoundation.org, www.socialinnovationeurope.eu, www.sidrive.eu, www.ssireview.org, www.oecd-ilibrary.org, www.innovativelatvia.lv, socialinnovation.lv, izm.izm.gov.lv, www.lm.gov.lv, www.birdhub.eu, www.em.gov.lv, www.vraa.gov.lv, www.liaa.gov.lv, likumi.lv web-sites.

More than 70 references were analysed including journal articles; $\mathrm{PhD}$ and MA theses; conference proceedings; PowerPoint presentations; project deliverables (reports, handbooks, reviews, guides, policy documents) developed 
by The Young Foundation \& NESTA, OECD, TEPSIE, SI-DRIVE, Social Innovation Europe Initiative, Bureau of the European Policy Advisers (BEPA) under the supervision of the European Commission).

This paper focuses on the analysis of the role of education in promoting social innovation processes in the society. The main findings are given in two parts: 1) state-of-the-art review of the development and research of social innovation; 2) interaction between social innovation and education with two conceptual models elaborated by the authors. Together with conclusions further research directions are specified in the context of the empirical part of the research.

\section{State-of-the-art review of the development and research of social innovation}

There are many definitions of social innovation in use without explicit and uniform theorizing of the concept, therefore as argued by Oeij et al. (2011), "social innovation is about everything and nothing at the same time" (p. 40). For the purpose of this paper the authors use the definition of social innovations as “...new solutions (products, services, models, markets, processes etc.) that simultaneously meet a social need (more effectively than existing solutions) and lead to new or improved capabilities and relationships and better use of assets and resources. In other words, social innovations are both good for society and enhance society's capacity to act." proposed by partnership of TEPSIE project (The Young Foundation, 2012, p. 18; Krlev et al., 2014, p. 201).

According to European Commission (2011) and Bonifacio (2014), there are three key approaches to social innovation:

- The social demand approach (the 'ghetto' view) which responds to social demands that are traditionally not addressed by the market or existing institutions and are directed towards vulnerable groups in society. They have developed new approaches to tackling problems affecting youth, migrants, the elderly, socially excluded, etc.

- The societal challenge approach (the 'reformist' view) focuses on innovations for society as a whole through the integration of the social, the economic and the environmental. Societal challenges in which the boundary between 'social' and 'economic' blurs, and which are directed towards society as a whole.

- The systemic change approach (the 'empowering' view), the most ambitious of the three and to an extent encompassing the other two, is achieved through a process of organizational development and changes in relations between institutions and stakeholders. The process of reforming society in the direction of a more participative arena where empowerment and learning are sources and outcomes of well-being (EC, 2011, p. 36-38; Bonifacio, 2014, p. 153-154). 
This theoretical study reveals a number of concepts which are interrelated to social innovation in multiple ways being embedded within theoretical and empirical underpinnings of social innovation:

- $\quad$ social system (Cajaiba-Santana, 2013; McCarthy et al., 2014; Westley et al., 2014);

- $\quad$ social value (Le Ber \& Branzei, 2010; Minks, 2011; Bonifacio, 2014);

- $\quad$ social problems (Minks, 2011);

- $\quad$ social challenges (The Young Foundation, 2012; EC, 2011);

- $\quad$ social impact (Ortega et al., 2014);

- social change / transformation (OECD, 2010; Dover, 2011; Minks, 2011; EC, 2011; Cajaiba-Santana, 2013; Westley et al., 2014);

- $\quad$ system change (OECD, 2010; Nichols et al., 2013; Westley et al., 2014);

- $\quad$ social quality (Oeij et al., 2011; Li et al., 2012);

- quality of life (Pol \& Ville, 2009; OECD, 2010; Li et al., 2012; Edwards-Schachter et al., 2012; Bonifacio, 2014);

- $\quad$ quantity of life (Pol \& Ville, 2009);

- well-being, welfare (OECD, 2010; Edwards-Schachter et al., 2012; Bonifacio, 2014);

- $\quad$ social action (Cajaiba-Santana, 2013; Bhatt \& Altinay, 2013);

- $\quad$ social capital (Bhatt \& Altinay, 2013);

- $\quad$ social practices (Oeij et al., 2011; Cajaiba-Santana, 2013; Howaldt et.al., 2014; Klievink \& Janssen, 2014);

- $\quad$ cross-sector partnership (Le Ber \& Branzei, 2010; Jiménez Escobar \& Morales Gutiérrez, 2011);

- relationships (OECD, 2010; Li et al., 2012; Klein et al., 2012; Nichols et al., 2013; Klievink \& Janssen, 2014), etc.

This literature review presents core elements and common features of social innovation (Minks, 2011; Edwards-Schachter et al., 2012; The Young Foundation, 2012; Bulut et al., 2013; Ümarik et al., 2014), typology of social innovation (Nambisan, 2009, cited in Lundstrom \& Zhou, 2011; The Young Foundation, 2012; Davies, 2014) as well as fields, sectors, and levels of social innovation (The Young Foundation, 2012; Bund et al., 2013; Bonifacio, 2014). The most crucial analytical dimensions and models of social innovation which could be used in the further empirical research are determined to be:

- the systemic model for social impact innovation (Ortega et al., 2014);

- the conceptual model or heuristic of social innovation (McCarthy et al., 2014);

- the conceptual model of the social innovation process (CajaibaSantana, 2013);

- the relevant building blocks of innovation studies and key dimensions of social innovation (Howaldt et al., 2014); 
- the integrated model for measuring social innovation (Bund et al., 2013; Krlev et al., 2014);

- the six stage process of social innovation (Murray et al., 2010; The Young Foundation, 2012);

- the policy analytical dimensions concerning social innovation (Lundstrom \& Zhou, 2011).

- the citizen engagement in social innovation (Davies \& Simon, 2012) including a typology for mapping citizen engagement in the social innovation process as well as functions and examples of engagement;

- the structural and agency barriers to social innovation (Mendes et al., 2012).

Recent studies (Pol \& Ville, 2009; Edwards-Schachter et al., 2012; Cajaiba-Santana, 2013; Ümarik et al., 2014) have shown that the concept of social innovation is used in various and overlapping ways in different disciplines; the research on social innovation is highly diversified, fragmented and includes interdisciplinary approaches to social innovation from different fields such as territorial and urban development, sociology, public administration, social entrepreneurship, history, economics, social psychology, management, social movements, creativity, political science, communication technologies, environmental sciences, human services, etc.

Many researchers are dissatisfied with the current situation in the field of social innovation studies, because a more coherent concept of social innovation is needed (Oeij et al., 2011). In order to provide a more holistic view of the phenomenon of social innovation (Cajaiba-Santana, 2013) as a complex, multidimensional concept (Edwards-Schachter et al., 2012), context-dependent phenomenon, strongly influenced by the socio-cultural, institutional and geographical background of the actors involved (Howaldt et al., 2014), the systemic understanding of the development and research of social innovation is needed. For that research should be based, for instance, on:

- $\quad$ systems ecological approach (Nichols et al., 2013);

- perspectives of social constructionism, sensemaking, and story-telling (Cajaiba-Santana, 2013);

- $\quad$ design approach (Murray et al., 2010; Hillgren et al., 2011);

- participatory design (Hillgren et al., 2011); community-based, collaborative and/or interdisciplinary research (Nichols et al., 2013);

- multiple case study approach, conducting interviews, observing meetings and events (Dover, 2011); comparative case study research, conducting in-depth interviews (Le Ber \& Branzei, 2010); case studies by conducting qualitative semi-structured interviews with individuals directly involved in the spreading social innovation (Davies, 2014);

- $\quad$ survey method (Bulut et al., 2013). 
The concept of social innovation is still relatively new in Latvia; therefore it is to be researched and comprehended by the society. That requires theoretical and empirical community-based, collaborative and interdisciplinary research on social innovation in Latvia. This process has been triggered by Social Innovation Centre (socialinnovation.lv) which has initiated open discussion on social innovation in Latvia.

\section{The interaction between social innovation and education}

The model of interaction between social innovation (SI) and education (E) revealed in the course of this research is depicted in Figure 1.

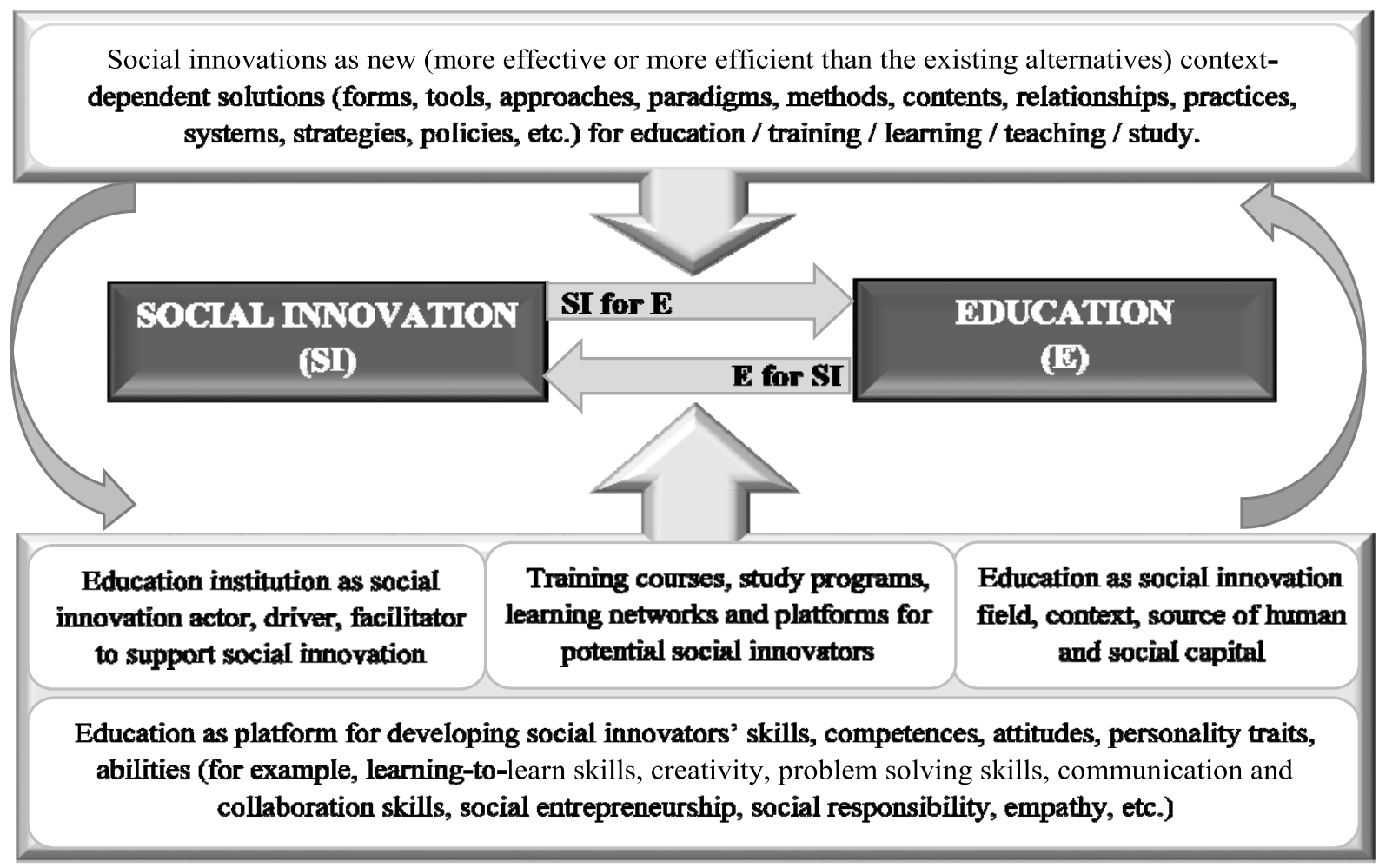

Figure 1. A conceptual model of interaction between social innovation and education (elaborated by the authors)

The central part of the Figure 1 shows the two directions of interaction between social innovation and education based on the motto "Innovating to learn, learning to innovate" (OECD, 2008):

- $\quad \boldsymbol{S I}$ for $\boldsymbol{E}$ (see Figure 1): Social innovation for education concerns new solutions (forms, tools, approaches, paradigms, methods, contents, relationships, practices, systems, strategies, policies) for supporting, improving quality and transforming of education / training / learning / teaching / study (Pol \& Ville, 2009; OECD, 2008, 2013; EC, 2011; Bulut et al., 2013; Krlev et al., 2013; Ümarik et al., 2014); 
- $\quad \boldsymbol{E}$ for $\boldsymbol{S I}$ (see Figure 1): Education for social innovation relates to the development of the set of skills, competences, attitudes, personality traits and abilities needed for making social innovations come true. Education institutions play an important role as social innovation actors, drivers and facilitators to support social innovation and realise training courses, study programs and learning networks for potential social innovators (TEPSIE, 2014). Education is determined to be one of social innovation fields (Bund et al., 2013) with powerful source of human and social capital which create an appropriate context for developing social innovation ecosystem (EC, 2011; Mancabelli, 2012; Nichols et al., 2013; Bhatt \& Altinay, 2013; TEPSIE, 2014).

According to Andrew and Klein (2010, p. 22-23), "Social innovation requires learning and institutional capacity to learn. 'Learning regions' and 'learning institutions' are therefore critical elements in the social innovation processes" (cited in Edwards-Schachter et al., 2012, p. 680). Collective process of learning is one of the characteristics of social innovation obtained from the analysis of 76 definitions by Edwards-Schachter et al. (2012). Lack of capacity for organisational learning at all levels is one of the barriers to social innovation in the public sector (Mendes et al., 2012). According to Mancabelli (2012), "to become 21 st-century innovators, we must first become 21 st-century learners" (p. 74). It is necessary to focus on the social mechanism of innovation (e.g., social learning) (Howaldt et al., 2014). Promoting a learning culture and developing an infrastructure for social innovation involves changing minds and practices, it calls for ongoing mutual learning (EC, 2011). Knowledge mobilization processes facilitate interdisciplinary learning and organising studies to support of social innovation (Nichols et al., 2013).

The general types of training of potential social innovators were identified within TEPSIE (2014) project as: tailored courses for interested persons offered by training centres; university programmes for social innovators; certificates for volunteers; learning networks; subsidized secondments; mobility schemes. Furthermore, according to TEPSIE (2014), "growth extends beyond just the number of social innovation courses offered at colleges / universities globally, to an equally impressive increase in the number of disciplines and thematic focus areas represented by those social innovation courses" (p. 74). The role of education varied depending on the approaches to social innovation (see Table 1). These three approaches to social innovation are not mutually exclusive, but rather interdependent parts of a common framework: the first approach is the background for the second, which creates the conditions for the third (EC, 2011; Bonifacio, 2014). 
Table 1. The role of education within three key approaches to social innovation (analysed, systemised and tabled by the authors)

\begin{tabular}{|c|c|c|}
\hline \multicolumn{2}{|c|}{$\begin{array}{l}\text { Some measures related to capacity building / } \\
\text { recognition and research for a European } \\
\text { Social Innovation Initiative (EC, 2011, p. } \\
123-124)\end{array}$} & $\begin{array}{l}\text { Some domains of the role of education } \\
\text { in promoting social innovation } \\
\text { processes }\end{array}$ \\
\hline $\begin{array}{l}\text { Approach 1: Social } \\
\text { needs } \\
\text { Goal: Boost social } \\
\text { innovation as an } \\
\text { instrument of social } \\
\text { and employment } \\
\text { policies (Europe } 2020 \\
\text { 'inclusive growth'). }\end{array}$ & 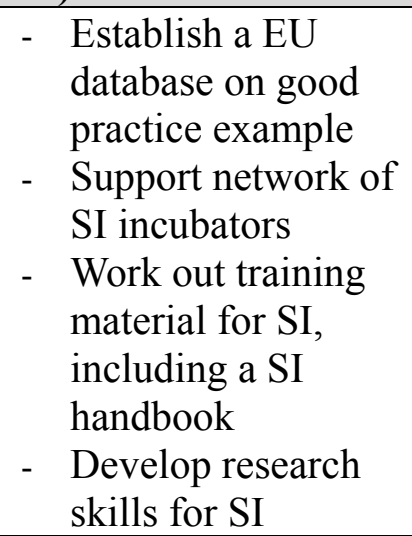 & $\begin{array}{l}\text { Education as one of social needs to be } \\
\text { met and one of social issues to be } \\
\text { solved (Lundstrom \& Zhou, 2011) } \\
\text { - Workplace learning, learning by } \\
\text { doing, experience-based learning, } \\
\text { research-based learning as a basis for } \\
\text { promoting SI } \\
\text { - Inclusive education, second chance } \\
\text { education as SI field }\end{array}$ \\
\hline $\begin{array}{l}\text { Approach 2: Societal } \\
\text { challenges } \\
\text { Goal: Enlarge the } \\
\text { remit to societal, } \\
\text { environmental and } \\
\text { global challenges } \\
\text { (Europe } 2020 \\
\text { 'sustainable growth') }\end{array}$ & $\begin{array}{l}\text { - Create Master } \\
\text { module for training } \\
\text { SI } \\
\text { - } \quad \text { Create EU status } \\
\text { and } \\
\text { professionalization } \\
\text { (skills) of SI }\end{array}$ & $\begin{array}{ll}\text { - } & \text { Education as societal challenge } \\
\text { - } & \text { Professionalization of SI and } \\
\text { development of the skills of social } \\
\text { innovators as a basis for promoting SI } \\
\text { (TEPSIE, 2014) } \\
\text { - } \text { Interdisciplinary learning, lifelong } \\
\text { learning and life-wide learning as SI } \\
\text { field }\end{array}$ \\
\hline $\begin{array}{c}\text { Approach 3: } \\
\text { Systemic changes } \\
\text { Goal: Build a } \\
\text { responsive society for } \\
\text { enabling innovation } \\
\text { (Europe } 2020 \text { 'smart } \\
\text { growth') }\end{array}$ & $\begin{array}{ll}\text { - } & \text { Develop open } \\
\text { social innovation } \\
\text { digital platforms } \\
\text { - } & \text { Provide active } \\
\text { citizenship training } \\
\text { modules } \\
\text { - } & \text { Carry out } \\
\text { education reforms } \\
\text { for mutual learning } \\
\text { and participative } \\
\text { citizenship }\end{array}$ & $\begin{array}{l}\text { - Education opportunities (including } \\
\text { quality of teaching and learning } \\
\text { practices) as elements of the } \\
\text { determinants of the quality of life (Pol } \\
\text { \& Ville, 2009) } \\
\text { - Empowerment and learning as sources } \\
\text { and outcomes of well-being (EC, } \\
\text { 2011; Bonifacio, 2014) } \\
\text { - Participatory workshops as examples } \\
\text { of problem solving being one of the } \\
\text { functions of citizens' engagement in } \\
\text { SI (Davies \& Simon, 2012) } \\
\text { - Education as a profession or sector for } \\
\text { spreading SI (NESTA, 2008, cited in } \\
\text { OECD, 2010) } \\
\text { - E-learning, interactive social learning, } \\
\text { collaborative learning, problem-based } \\
\text { learning, interdisciplinary learning as } \\
\text { a basis for promoting SI } \\
\text { - Mutual learning and participative } \\
\text { citizenship as SI field }\end{array}$ \\
\hline
\end{tabular}


Based on the analysis carried out in Table 1, a conceptual model of the triple role of education in promoting social innovation was elaborated (see Figure 2).

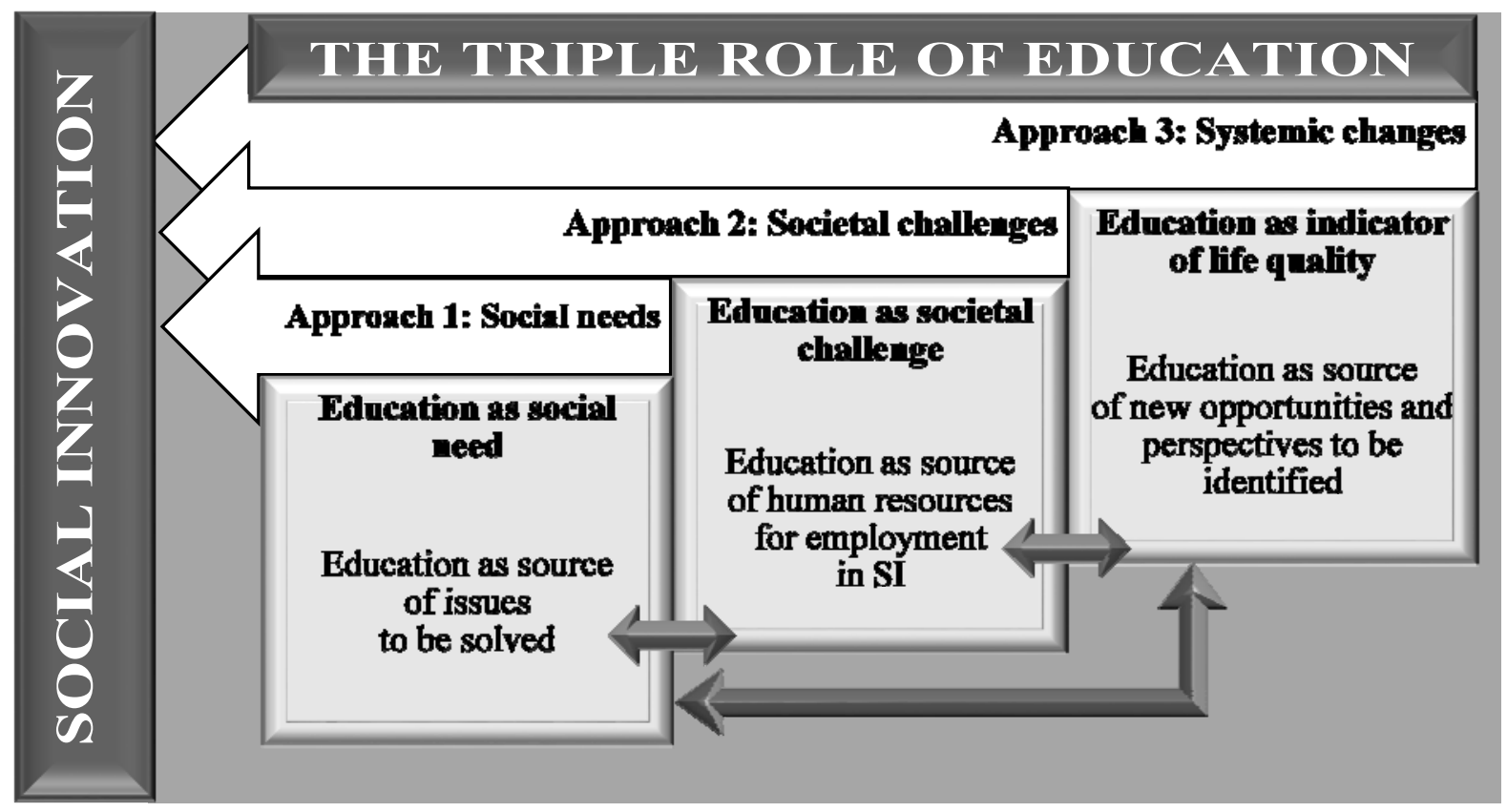

Figure 2. A conceptual model of the triple role of education in promoting social innovation (elaborated by the authors)

The three components of the role of education in promoting social innovation are interdependent; moreover the triple role of education as source of topical issues, human resources and new opportunities should be perceived, comprehended, researched and developed within a holistic perspective.

\section{Conclusions}

The concepts of education and social innovation are interrelated. Education has triple role in promoting social innovation processes in the society. The three components of this role (social need, societal challenge and indicator of life quality) are interdependent; that requires a holistic view of the triple role of education as source of topical issues, human resources and new opportunities and perspectives.

The concept of social innovation is still relatively new in Latvia; therefore it is to be studied and comprehended by the society via conducting empirical community-based, collaborative and interdisciplinary research on social innovation in Latvia. It requires the elaboration of interdisciplinary methodology for empirical research on social innovation in Latvia within and crossing the fields of education, economics, regional development, etc. 
The paper was supported by the National Research Program 5.2. "Economic Transformation, Smart Growth, Governance and Legal Framework for the State and Society for Sustainable Development - a New Approach to the Creation of a Sustainable Learning Community (EKOSOC-LV)"

\section{References}

Bhatt, P., \& Altinay, L. (2013). How social capital is leveraged in social innovations under resource constraints? Management Decision, 51(9), 1772 - 1792.

Bonifacio, M. (2014). Social innovation: A novel policy stream or a policy compromise? An EU Perspective. European Review, 22(1), 145-169.

Bulut, C., Hakan, E., \& Duygu Seckin, H. (2013). Social innovation and psychometric analysis. Procedia - Social and Behavioral Sciences, 82, 122-130.

Bund, E., Hubrich, D.-K., Schmitz, B., Mildenberger, G., \& Krlev, G. (2013). Blueprint of social innovation metrics - contributions to an understanding of opportunities and challenges of social innovation measurement. A deliverable of the TEPSIE project. Brussels: European Commission, DG Research.

Cajaiba-Santana, G. (2013). Social innovation: Moving the field forward. A conceptual framework. Technological Forecasting and Social Change, 82, 42-51.

Davies, A., \& Simon, J. (2012). Citizen engagement in social innovation - a case study report. A deliverable of the TEPSIE project. Brussels: European Commission, DG Research.

Davies, A. (2014). Spreading social innovations: A case study report. A deliverable of the TEPSIE project. Brussels: European Commission, DG Research.

Dover, G. (2011). Social innovation and institutional work: A study of the role of place and place-making in social innovations for the "Hard-to-House". Dissertation submitted in partial fulfillment of the requirements for the degree of doctor of philosophy in the Faculty of Business Administration. Simon Frazer University, Canada.

Edwards-Schachter, M. E., Matti, C. E., \& Alcántara, E. (2012). Fostering quality of life through social innovation: A living lab methodology study case. Review of Policy Research, 29(6), 672-692.

EC, European Commission. (2011). Empowering people, driving change: Social innovation in the European Union. Bureau of the European Policy Advisers, European Commission.

Hillgren, P.-A., Seravalli, A., \& Emilson, A. (2011). Prototyping and infrastructuring in design for social innovation. CoDesign, 7(3/4), 169-183.

Howaldt, J., Butzin, A., Domanski, D., \& Kaletka, C. (2014). Theoretical approaches to social innovation - a critical literature review. A deliverable of the SI-DRIVE project. Dortmund: Sozialforschungsstelle

Jiménez Escobar, J., \& Morales Gutiérrez, A. C. (2011). Social economy and the fourth sector, base and protagonist of social innovation. CIRIEC - España, Revista de Economía Pública, Social y Cooperativa, 73, 33-60.

Klein, J.-L., Fontan, J.-M., Harrisson, D., \& Levesque, B. (2012). The Quebec system of social innovation. A focused analysis on the local development field. Finisterra: Revista Portuguesa de Geografia, 47(94), 9-28.

Klievink, B., \& Janssen, M. (2014). Developing multi-layer information infrastructures: Advancing social innovation through public-private governance. Information Systems Management, 31(3), 240-249.

Krlev, G., Glänzel, G., \& Mildenberger, G. (2013). Capitalising social innovation. A short guide to the research for policy makers. A deliverable of the TEPSIE project. Brussels: European Commission, DG Research. 


\section{SOCIETY. INTEGRATION. EDUCATION. Volume IV}

Krlev, G., Bund, E., \& Mildenberger, G. (2014). Measuring what matters - indicators of social innovativeness on the national level. Information Systems Management, 31(3), 200-224.

Le Ber, M. J., \& Branzei, O. (2010). (Re)forming strategic cross-sector partnerships: Relational processes of social innovation. Business \& Society, 49(1), 140-172.

Li, Y., Sun, Y., \& Lin, K. (2012). Social innovation, local governance and social quality: The case of intersectoral collaboration in Hangzhou city. International Journal of Social Quality, 2(1), 56-73.

Lundstrom, A., \& Zhou, C. (2011). Promoting innovation based on social sciences and technologies: The prospect of a social innovation park. Innovation: The European Journal of Social Sciences, 24(1/2), 133-149.

Mancabelli, R. (2012). Looking for 21st-century schooling? District Administration, 48(6), 74.

McCarthy, D. D. P., Whitelaw, G. S., Westley, F. R., Crandall, D. D., \& Burnett, D. (2014). The Oak Ridges Moraine as a social innovation: Strategic vision as a social-ecological interaction. Ecology \& Society, 19(1), 385-396.

Mendes, A., Batista, A., Fernandes, L., Macedo, P., Pinto, F., Rebelo, L., Ribeiro, M., Ribeiro, R., Sottomayor, M., Tavares, M., \& Verdelho, V. (2012). Barriers to social innovation. A deliverable of the TEPSIE project. Brussels: European Commission, DG Research.

Minks, M. (2011). Social innovation: New solutions to social problems. A Thesis submitted to the Faculty of the School of Continuing Studies and of the Graduate School of Arts and Sciences in partial fulfillment of the requirements for the MA degree of Arts in Liberal Studies.

Murray, R., Caulier-Grice, J., \& Mulgan, G. (2010). Ways to design, develop and grow social innovation: The open book of social innovation. The Young Foundation \& NESTA.

Nichols, N., Phipps, D. J., Provençal, J., \& Hewitt, A. (2013). Knowledge mobilization, collaboration, and social Innovation: Leveraging investments in higher education. Canadian Journal of Nonprofit \& Social Economy Research / Revue canadienne de recherche sur les OSBL et l'économie sociale, 4(1), 25-42.

Oeij, P. R. A., Dhondt, S., \& Korver, T. (2011). Workplace innovation, social innovation, and social quality. International Journal of Social Quality, 1(2), 31-49.

Ortega, S., Furr, N., Liman, E., \& Flint, C. (2014). The science of social impact innovation: How to deliver more impact through innovative business models. International Journal of Innovation Science, 6(2), 73-82.

OECD (2008). Innovating to learn, learning to innovate. Centre for Educational Research and Innovation, OECD Publishing.

OECD (2010). SMEs, entrepreneurship and innovation. Series: OECD Studies on SMEs and Entrepreneurship. OECD Publishing.

OECD (2013). Innovative learning environments. Series: Educational Research and Innovation. Centre for Educational Research and Innovation, OECD Publishing.

Pol, E., \& Ville, S. (2009). Social innovation: Buzz word or enduring term? The Journal of Socio-Economics, 38(6), 878-885.

The Young Foundation (2012). Social innovation overview - Part I: Defining social innovation. A deliverable of the TEPSIE project. Brussels: European Commission, DG Research.

TEPSIE. (2014). Building the social innovation ecosystem. A deliverable of the TEPSIE project. Brussels: European Commission, DG Research.

Ümarik, M., Loogma, K., \& Tafel-Viia, K. (2014). Restructuring vocational schools as social innovation? Journal of Educational Administration, 52(1), 97 - 115. 
Westley, F., Antadze, N., Riddell, D. J., Robinson, K., \& Geobey, S. (2014). Five configurations for scaling up social innovation: Case examples of nonprofit organizations from Canada. The Journal of Applied Behavioral Science, 50(3), 234-260. 